\title{
A Pedagogical Example of Teaching Universal Access
}

\author{
Simeon Keates \\ Faculty of Engineering and Science, University of Greenwich, Medway Campus, \\ Central Avenue, Chatham Maritime, Kent ME4 4TB, UK \\ s.keates@gre.ac.uk
}

\begin{abstract}
Designing for Universal Access requires designers to have a good understanding of the full range of users and their capabilities, appropriate datasets, and the most suitable tools and techniques. Education clearly plays an important role in helping designers acquire the knowledge and skills necessary to find the relevant information about the users and then apply it to produce a genuinely inclusive design. This paper presents a reflective analysis of a variant of the "Usability and Accessibility" course for M.Sc. students, developed and delivered by the author over 5 successive semesters at the IT University of Copenhagen. The aim is to examine whether this course provided an effective and useful method for raising the issues around Universal Access with the designers of the future. This paper examines the results and conclusions from the students over 5 semesters of this course and provides an overview of the success of the different design and evaluation methods. The paper concludes with a discussion of the effectiveness of each of the specific methods, techniques and tools used in the course, both from design and education perspectives.
\end{abstract}

Keywords: usability, accessibility, universal access, education 


\section{Introduction}

It is widely accepted that there is a need to adopt user-centred [Vredenburg et al., 2002] or user-sensitive [Newell and Gregor, 2000] design processes when designing user interfaces. It is also widely accepted that there is a need to design for the widest possible range of users [Marcus, 2003]. Design approaches such as Universal Design [Vanderheiden and Tobias, 2000; Follette Story, 2001], Inclusive Design [Clarkson et al., 2003], and Countering Design Exclusion [Keates and Clarkson, 2003] have been developed as means of ensuring that user interfaces support the concept of Universal Access [Stephanidis, 2009]. However, it is unusual to find any of these concepts taught explicitly within university Computer Science or Engineering Design degree programs. Often they are taught within modules such as Interaction Design, if at all, and usually only make up a few hours of the teaching material being delivered.

This paper describes a combined Usability and Accessibility course for graduate students, which was developed to introduce students with basic computing skills to both topics. The aim of this paper is to introduce the content of, and rationale for, the course, and also to reflect on the experience of delivering the course, student responses and also the effectiveness of the various tools and techniques presented to the students. The course went through a number of iterations and this paper is intended to provide food for thought for those designing similar courses, rather than holding this course up as an exemplar of best practice.

\section{The "Usability and Accessibility" Course}

The purpose of the "Usability and Accessibility" course, and its predecessor "Usability with Project" course, was to provide students with the knowledge and skills to be able to identify and design for the needs of the widest possible range of users. A high proportion of the students taking the course intended to become practicing designers, particularly in the area of Web design.

This focus of the course was on teaching the principles of designing for Universal Access by practice and not solely by theory. To facilitate this learning by practice, the students had to develop a web-shop in the first two weeks of the course and 
then modify a copy of the web-shop using the theory they were taught during the lectures and the practical skills acquired during the practical exercise sessions.

Initially, the course was called "Usability with Project," but was re-named to reflect the actual course content more accurately in Spring 2010. The course was taught in the third semester of the 2-year M.Sc. degree within the Design and Digital Communication (DDK) programme at the IT University of Copenhagen. The course was part of the User-Centred Design specialism within the DDK programme.

Students on the DDK programme typically come from a wide variety of backgrounds. Approximately half of the students attending the course will have received a traditional Computer Science education. The remaining students will have usually had a more humanities-based education and would be looking to acquire computing skills to help them pursue more technical career opportunities. The students are typically mature and either returning to education after a few years of work experience or completing the degree as part of their on-the-job training. Almost all of the students described their interest and motivation for taking the Usability and Accessibility / Usability with Project course as being to learn how to make websites more usable, even though websites were not explicitly mentioned in the course description.

The DDK programme consists of a mix of mandatory courses and voluntary ones. A typical full course structure is shown in Table 1.

\section{INSERT TABLE 1 ABOUT HERE}

The "Usability and Accessibility" course was a specialism option in the 3rd semester. Other choices included:

- "Digital culture and community"

- "Globalisation, organisation and communication"

- "Digital aesthetics: theory and practice"

- $\quad$ "Mobile communication: design-related, business-related and social context" 
These are all 15 ECTS courses, constituting one-eighth of the 2-year 120 ECTS M.Sc. course.

\section{Course Structure}

The version of the "Usability and Accessibility" under consideration here was 15 weeks long and, as discussed earlier, structured around the development of a web shop. In the first teaching session, the students are asked to interview each other and to complete a skills and interests questionnaire. The questionnaire included the following questions:

- What keywords describe your background?

- What keywords describe your professional interests?

- What previous experience do you have of practical usability work?

- What experience do you have in creating a simple website in PHP, HTML and CSS?

- Did you take the Experimental Design and Analysis course?

Regarding the last question, the Experimental Design and Analysis course was introduced as a precursor course to the Usability and Accessibility one and was taught in the preceding semester. It became necessary to introduce this course after it was found that many of the students did not understand basic probability. The Experimental Design and Analysis course provided a comprehensive introduction to common statistical methods used in user studies.

From the information provided in these questionnaires, the students were placed into groups of 4 or 5 students with at least 2 experienced programmers in each group, although all students would have taken the earlier mandatory courses on Databases, which covered the basics of PHP programming, and Web Design, which introduced HTML, XML and the basics of Javascript.

\subsection{Project Initiation}

Once students had been placed in their groups of 4 , they were tasked with building a simple web-shop in the first 2 weeks of the semester. The students were 
informed that if the website was not working by the following Friday, they would fail the course. No group failed to submit a working web-shop by the deadline. The tight deadline was chosen specifically to emulate the time pressure that most designers and developers experience in commercial environments, where there is often a deadline to be met. No explicit usability or accessibility criteria were presented to the students. The intention was to help students recognize in retrospect, at the end of the course, how easily such criteria can be overlooked in the rush to meet a deadline and also to examine Alan Cooper's assertion that unless otherwise directed, designers will typically design for themselves [Cooper, 1999]. Such experiences have been noted in earlier access to industry attitudes to Universal Access [Keates, Lebbon and Clarkson, 2000].

The design brief that they were given stated that:

1. The students had been hired by a fictional Danish company to produce a web-shop within 2 weeks to offer a list of specified British products to their employees as a reward for a record-breaking year of sales.

2. The web-shop was to consist of a welcome/splash page explaining the offer, a product selection page, a delivery page and an order confirmation page.

3. Each employee had to either choose a single product (first two iterations of the course) or was to receive between 5 and 10 stars to spend (all other iterations). All stars had to be "spent" in a single order to reduce delivery costs before the order can be completed.

The students were then given a list of between 60 and 75 British products to offer on their web-shop. A number of those products were deliberately chosen to be unfamiliar to non-British people. Examples of potentially misleading product names included:

- Mince pies - a type of dessert, not a meat pie

- Yorkshire puddings - an entrée side dish, not a dessert

- Christmas crackers - a kind of toy, not a type of biscuit

- Old Speckled Hen - a kind of beer, not poultry

Some of the products were very economical, such as Heinz and McVitie's. Others were from premium brands, such as Fortnum and Mason or Hamley's. 
The aim was to encourage the students to learn to research products for themselves and also to ensure that their web-shops communicate the nature of the products effectively, rather than simply relying on brand and product name familiarity to the users. Between $30 \%$ and $50 \%$ of the products on the list were changed each time the course ran, both to minimize the possibility of designs being passed down from one student cohort to another. These measures ensured that each web-shop design was unique and no duplication of designs was detected between each of the iterations of the course.

The change from selecting a single product to spending 10 stars was made because although the newer project was more complex to code, it offered a richer interaction and thus more data to analyse in the final reports.

Having developed a working web-shop, the students then had to improve the design through the application of usability and accessibility methods.

Those initial versions of the web-shop were then frozen, i.e., saved in a secure location that the students could not access, as unmodified versions of the initial design would be required later in the course. The web-shop was copied and made available to the students and over the next 10 weeks of the course, usability and accessibility theory, practices and tools were introduced. The students developed the duplicate version of the web-shop, this time with explicit consideration of the usability and accessibility requirements of the users.

\subsection{Taught Content}

The usability and accessibility theories that the students were introduced to were presented in an ordered sequence designed to support the continuing development and refinement of their web-shops. The course was expected to take 20 hours per week of student time, with 2-hour lectures and 2-hour practical exercise sessions twice a week (typically Wednesdays and Fridays), giving 8 hours of direct tuition per week and the remainder of the time being self-guided tuition by the students. The self-guided periods included reading the recommended academic and 
professional practice papers, writing up reports from the practical exercise sessions, and design and development work on the modified web-shop.

Usually, the first morning of lectures in any particular week would introduce new theory. The first exercise session, that same afternoon, was focused on applying that theory in a more generic exercise that was complementary to the project, but did not involve the web-shops developed by the students. The second morning of lectures then examined the application of the theory and introduced further theory to build on that learnt earlier in the week. The second afternoon of exercises was then focused on applying the theory to the web-shop project.

An example lecture/exercise plan is shown in Table 2. Sample course blogs, including all lecture notes and handouts are available at:

1. http://usability08.wordpress.com/

2. http://usability09.wordpress.com/

\section{INSERT TABLE 2 ABOUT HERE}

\subsection{Project Conclusion}

At the end of the semester, the students were asked to prepare a 10-page project report in the ACM CHI publication format [ACM, 2013] along with a 5-page supplementary report, which could be formatted to their own choice. They were examined on a combination of the 10-page report, a 20 minutes group presentation and 20 minutes individual oral examinations. The students were told to focus on being able to justify quantitatively whether their revised sites were more usable and accessible than their original (frozen) sites.

\subsection{Course Participants}

In total, 116 students enrolled in the course over the 5 semesters discussed in this paper. Between them, they developed 48 different web-shops - 24 original (frozen) versions and 24 revised versions in groups of 3 to 5 students. 


\subsection{Usability Methods}

The students were introduced to usability methods in both increasing complexity, but also in an order that made sense for the re-design of their web-shop.

Card sorting. Card sorting [Hudson, 2005] was used by the students to decide on the best potential clusters for their products (e.g. Sweets, Healthcare products) and also to ensure that the products were in the correct cluster / category. They were introduced to the concept of card sorting through an exercise to arrange bank savings products on a kiosk with 6 buttons, similar to designing for an ATM. The students had to explore how best to categorise the different products to minimize the expected number of button presses for a user to find a random bank savings product from the list provided. Based on their experience from this exercise, they were instructed to consider the optimal clusters for the list of British products for their web-shops. They had to consider balancing standard breadth versus depth issues for mathematically optimal searching against the more "natural" clusters of the products, such as Food or Travel. Note that the products had not been chosen to form equally sized clusters to ensure that the students had to balance the different clustering requirements.

Personas. Personas are usually developed from a known user group and are typically used to describe particular sectors of the target users that are of specific interest to the designers [Adlin and Pruit, 2010]. In this case, though, since the target user group was fictional, the students were required to envisage fictional personas that represented broad user types. The intention was to encourage the students to consider different patterns of user behavior. These included factors such as:

- Time to complete - some users may be pushed for time, others may have more time available

- Certainty about the products - some users may know about the products, others may not

- Value for money - some users may be focused on optimizing the value for money of their selection, others may be more interested in other factors

- Decisiveness - some users may choose products on the first viewing, others may need more time to consider their choices in more detail 
- Suspiciousness - some users may trust the site, others may not

The students were encouraged to consider personas that represented cross-sections of the above factors and would be used in conjunction with heuristic evaluations and cognitive walkthroughs.

Heuristic evaluation / cognitive walkthroughs. Here a cognitive walkthrough is taken to mean the simulation of a specified task, whereas heuristic analysis is the more comprehensive overview of all aspects of the web-shop [Nielsen, 1993; Nielsen and Mack, 1994]. The students developed specific use cases based on the personas that they had developed and then performed heuristic evaluations and cognitive walkthroughs to identify potential usability issues with their "frozen" sites. They also performed similar evaluations on at least one other group's webshop. The purpose of the competitor analysis was to help the students consider their own designs and whether there were features that could be added to their own web-shop. The evaluations were also shared with the other group, so each group got an independent assessment of their own web-shop.

User trials. At the end of the semester the students performed user trial evaluations of their original (frozen) and revised sites. They had to recruit a minimum of 4 users in the first two iterations of the course and later 6 users, and an additional user who was blind. No assistance was given in finding the blind user to encourage the students to learn where to find such users. Before conducting the final set of user trials, they also had to perform a pilot study with at least one other user. The students typically used screen-recording software, such as Silverback or Camtasia, to record the trials. They were encouraged to collect as much quantitative data as possible. The students were required to prepare a strategy for the user trials, including scripts and tasks. Those had to be modified, where necessary, for the blind users.

\subsection{Accessibility Methods}

The stipulation that at least one of the users in the final user trials had to be blind meant that each group had to explicitly consider the accessibility of their webshop. To this end, the students were introduced to common accessibility evaluation tools. 
Cynthia Says. The students were first asked to use HiSoftware's Cynthia Says Portal [HiSoftware, 2013] to identify how many Web Content Authoring Guidelines (WCAG) Priority 1, 2 and 3 errors [Thatcher et al., 2006] their sites had. Although WCAG is commonly accepted as the default standard for web accessibility in the Universal Access community, this was the first time almost all of the students had encountered it. Typically, only the students who had worked for large multinational organisations, such as Microsoft, were aware of the WCAG standards.

WAVE. Cynthia Says produces a list of potential compliance issues for each website assessed. However, many students found the Cynthia Says Portal output to be very difficult to visualise, and so they were asked to repeat the WCAG evaluation using WebAIM's WAVE Web Accessibility Evaluation Tool [WebAim, 2013], which produces a marked up version of the web page being analysed, with red, yellow and green markers indicating the location of potential problems (the yellow and red markers) or successes (the green markers).

Vischeck. About $8 \%$ of the male population is colour blind, so to check whether this presented a problem to users of their sites, the students were instructed to evaluate their sites using Vischeck [Vischeck, 2008]. The aim was to establish whether users with Deuteranopia (red/green colour deficit), Protanopia (red/green colour deficit) or Tritanopia (blue/yellow colour deficit) would experience difficulties using their sites.

Screen reader. The students were instructed to write a report explaining whether the websites they analysed conformed wholly to coding standards, using the WCAG compliance tools, and to see if there was a correlation between WCAG compliance and empirically determined accessibility when using a screen reader to navigate the specimen sites as well as their own web-shops. The students typically used WebAnywhere [Bigham and Prince, 2007] and JAWS [Freedom Scientific, 2013] as the screen readers to complete this practical exercise. 
Exclusion calculator. To evaluate the potential number of users that may be excluded from using their sites, the students were asked to perform a comparative exclusion analysis using either of the exclusion calculators developed by the Engineering Department at the University of Cambridge [CUED, 2005; CUED 2013]. The calculators required the students to estimate the levels of functional capability, e.g. vision, cognition, dexterity, etc., required to use a product and then report the total number of people within the British population who do not possess those levels of functional capability [see Keates and Clarkson, 2003 for working examples]. The aim of introducing the exclusion calculators was to indicate prevalence of impairment in the general population and the magnitude of people potentially excluded from using a particular design.

\section{Review of the Usability and Accessibility Methods}

As discussed above, the "Usability and Accessibility" course introduced the students to a number of common design and evaluation methods and tools. Some of those methods and tools were more successful than others. This section of the paper examines the student responses to the different stages of the course. The aim is to assist those designing similar courses to learn about what worked most effectively for this course and common student misunderstandings about the material.

\subsection{Initial Design Priorities}

None of the groups considered accessibility in their initial designs. Very few groups even considered usability objectives. Having been set the design task with the constraints provided, i.e., to build a working web-shop within two weeks or fail the course, their priorities naturally fell towards ensuring a working version of the web-shop.

Where the first versions of their web-shops were accessible, this was solely due to using valid HTML coding. This is both good in that it demonstrates that accessibility can be achieved by following standards. However the fact that no students considered accessibility until formally instructed to do so, is also concerning. 
Comparatively few groups considered explicit usability goals either. When they were considered, the goals were vaguely formulated often making reference to "user experience," but with no set targets or objectives. No group attempted to provide quantified usability or accessibility targets.

It was somewhat surprising that so few students even considered usability - even when the word was in the title of the course. However, this does support the general consensus in the literature that accessibility and usability are concepts that need to be considered explicitly in the design requirements, otherwise they will be overlooked in favour of other more overt objectives, such as making the design technically complete, i.e., with the specified features operational.

By the end of the course, though, all groups had clearly defined usability and accessibility objectives. By far the most common usability definition adopted was that from ISO 9241:11 specifically the "extent to which a product can be used by specified users to achieve specified goals with effectiveness, efficiency and satisfaction in a specified context of use" [ISO, 1998]. The most commonly adopted pragmatic interpretation of accessibility was broadly that the site must be "usable and accessible to a blind user using a screen reader". While this definition does not meet the usual definitions for Universal Access, i.e., to be as usable and accessible by as many people as possible in as many contexts of use as possible, it was considered to be a major step in the right direction.

\subsection{Usability and Accessibility Methods and Tools}

The card sorting exercises were useful in helping the students to consider their product groups and especially to identify products that were in the wrong product group. They found the basic principles straightforward to understand. Many of the groups had unknowingly used an ad hoc version of card sorting for their initial designs. However, those early attempts were based solely on putting the correct products into the most appropriate categories, led largely by "gut feel", i.e., what "felt" right. No systematic attempts were made to consider optimization of categories for user search efficiency. Once the mathematics underpinning the optimization of categories was introduced in the lectures, the students were able to 
reconsider their clustering of the products. In practice, though, the principal changes of products from one cluster/category to another were driven largely by whether a product had been misclassified in the initial design. By and large, the students preferred to retain their initial classifications and clustering of the products, irrespective of the mathematical optimization calculations.

The personas were not very useful in their traditional role in a user-centred design process. However, this was not surprising as they were entirely arbitrary constructs and not developed in the textbook way. They were useful, though, as a design tool in reminding the students that the users may exhibit a variety of browsing patterns and IT skills. The exercise of having to sit and consider different browsing, shopping and selection strategies was useful for the students even if the resultant personas were not technically correct. The most successful strategy observed for the students was a trio of personas that exhibited the following browsing patterns:

3. The quick user - someone who wants to complete the process as quickly as possible and did not want to re-visit the web-shop. This was likely to be someone who operated under a lot of time pressure or had other, more pressing, priorities to attend to.

4. The careful user - someone who wants to consider all of the possibilities to get the best possible value. This was considered to be someone who was careful with money and might seek out the best value options.

5. The uncertain user - someone who changes their mind frequently. This user might possibly visit the site multiple times before deciding and also possibly choose products based on someone else's recommendations. They might want to consider several products in a basket and then refine their choices iteratively.

The heuristic evaluations and cognitive walkthroughs were the first systematic attempt at understanding the usability of the web-shops by the students. As such, they responded positively to the structured nature of the assessments. They typically undertook structured tasks with optimal completion paths (cognitive walkthroughs) as well as more general reviews of the shops (heuristic analysis). However, these techniques did present difficulties of interpretation to the students. 
In the final user trial evaluations of the original and revised web-shops, the times when the users expressed a preference for the original site could in almost all circumstances be traced back to the heuristic evaluation stage. Heuristic evaluation is known to identify many potential usability issues on a website. However, the method provides comparatively little information about the priority of each issue. Effectively, the designers were presented with a long list of potential issues and little guidance on which ones were the most important.

Consequently, the students often assigned each issue the same priority and attempted to fix them all. In doing so, they sometimes ended up with a revised site that was visually more complex than the original site through the addition of FAQs, contact addresses, more robust error-checking, etc. They often missed out a reflective stage of taking a proverbial step backwards and re-considering the design as a whole once they had begun making their changes. This is akin to a car designer deciding that a car needs a bigger, more powerful engine, but forgetting to upgrade the clutch to support the higher engine power and torque and the suspension to support the increased weight, for example. In this case, the clutch would almost certainly burn out prematurely and the car would wallow around the corners with inadequate suspension. The designer needs to consider not only the engine, but also all of the other components that interact with it. The students sometimes did not realize that the same applies to web design. They sometimes considered that changing an icon or adding a new button, for example, were selfcontained modifications and sometimes forgot to consider whether those changes would affect the usability of the other on-screen elements and the general flow of the interaction with the site.

While the users often responded positively to the new additions to the site in terms of trustworthiness, for example, they also sometimes felt that the flow of the interaction had become more cumbersome and less streamlined. Many of the students managed to walk the fine line between providing a richer and more secure user experience without compromising the effectiveness of the site. Some groups, however, made their sites so complex that the user satisfaction was affected adversely. 
Finally, the user trials at the end of the semester were generally regarded by the students as the most useful usability evaluation method and the user trials with the blind users were often considered the most interesting and personally rewarding. However, it was also accepted that the user trials took much longer to plan and perform and were more resource intensive.

The pilot usability trials were also uniformly considered to be extremely useful, both in terms of refining the trial protocols and also providing last minute changes to the design of the web-shops.

\subsection{Accessibility Methods and Tools}

The students typically found the visual presentation of WCAG violations from WAVE to be extremely useful in identifying where the accessibility problems were on each page. WAVE generates screen shots with green, amber and red warning flags next to the on-screen elements, so students could see where the problems were on the screen. However, the detailed analytical feedback from Cynthia Says, which produces a list of issues with the HTML encoding including line numbers of the problematic code, was more useful in identifying where the problems lay within the coding. All groups used a combination of both applications in developing the revised versions of their web-shops, finding benefit in the combined strengths of both. However, most groups recognized that while these tools highlighted shortcomings in the coding, by themselves they were not enough to ensure that the final designs were genuinely accessible. Further tools and methods were required to accomplish that goal.

Vischeck was often harder for the students to interpret. A small number of groups (2) tried to adjust the colour schemes of their sites to still look visually appealing to themselves, while not appreciating that their colour preferences (with unimpaired colour vision) were not the same as for someone with a colour vision impairment. Most students, though, used Vischeck to look for insufficient colour contrast for each of the three colour vision impairment types, which was usually more successful and is the generally accepted correct use of the tool. 
The exclusion calculators usually did not offer enough data resolution to be able to respond to the changes made between the original and revised versions of each site, with often only minor differences in exclusion reported between the two versions. This was because the limiting factors in the ability to use the web-shops are imposed by the hardware used in the interaction (the keyboard, mouse and screen) rather than the design of the web-shops themselves. The largest discernible benefits were from increasing the font size to the equivalent of a large print book, which reduced exclusion from 1.313 million people (for small fonts) to 320000 for the Great Britain (GB) adult population of approximately 46.9 million people. Genuinely supporting screen reader use reduced this potential exclusion still further to effectively no exclusion for vision capability. However, the students recognized that users could still be excluded by:

- Cognitive demands - needing to understand the site and its operation typical exclusion estimate 1.88 million GB adults

- Dexterity - fine motor control for manipulating the mouse and keyboard typical exclusion estimate $944000 \mathrm{~GB}$ adults

- Reach and Stretch - putting the user's hands on the mouse and keyboard typical exclusion estimate 1.07 million GB adults

These magnitudes of exclusion surprised many of the students and led to discussion about the need to support alternative forms of input, such as speech recognition systems.

The accessibility tools that were most universally praised and used by the students were the screen readers. These demonstrated that websites which did not comply with HTML and WCAG standards were highly unlikely to work with the screen readers. However, they also showed that sometimes sites that passed the compliance tools were still fundamentally inaccessible because of flawed layouts and interaction design. For example, pages that did not use "Skip to Content" correctly or put the most commonly used functionality at the end of the screen readers' rendering of the pages were sometimes so frustrating to use that the pages were effectively inaccessible. The students found the screen readers to be straightforward to use and, by not looking at the screen as they were using them, found them to provide a good enough understanding of how a blind user would find navigating a site. 
The students, though, often over-compensated in their design corrections, usually by simplifying some functions more than necessary. They were usually surprised when they performed the user trials with the blind users at how rapidly the users would set the screen reader output. All of the students who expressed an opinion found the user trials with the blind users to be incredibly useful and fascinating. They responded positively to the challenges of designing for users who were often outside of their own direct experience.

Table 3 summarises the collected student views on each of the tools and methods used in the course.

INSERT TABLE 3 ABOUT HERE

\section{Review of the Course}

The "Usability and Accessibility" and "Usability with Project" courses were under constant review to keep them fresh and relevant to the students. The review process involved student feedback as well as setting new pedagogical and learning goals.

\section{Student Response to the Course}

Midway through each semester, the students on the course were invited to provide anonymised feedback through an online questionnaire. Responses were rated on a Likert scale of 1 ("I completely disagree") to 6 ("I completely agree").

The students were very satisfied overall with the course (response mean $=4.8$ out of 6.0 to the statement "Overall conclusion: I am happy about this course"). They also felt that the quantity of work on the course was about right (mean response = 3.4 out of 6.0 to the statement "My time consumption for this course is above the norm of about 20 hours/week") and that the course is highly relevant to their future employment (response mean $=5.1$ out of 6.0 to the statement "I think this course is highly relevant for my future job profile"). These results indicated that 
the students responded positively to this course. Qualitative feedback demonstrated very clearly that the students responded most positively to the very practical and applied nature of the course, with the focus on learning pragmatic skills rather than simply classroom theory.

\subsection{Course Name and Student Enrolment}

In Spring 2010, the name of the course was changed from "Usability with Project" to "Usability and Accessibility" although the content did not change noticeably. Figure 1 shows the student enrolment on the course before and after the name change. It can be clearly seen that student enrolment decreased from a mean of 24.7 students to 14 students per semester with the change in name of the course. This suggests that the concept of "accessibility" is still problematic in persuading students that this is a topic worthy of their attention. It is worth noting, though, that Denmark does not have a formal anti-discrimination law along the lines of the 1990 Americans with Disability Act [US DoJ, 1990] or the 1995 UK Disability Discrimination Act [HMSO, 1995]. Thus, it is not clear whether the student response to the course name change would be the same in countries where there is a clear legal imperative to consider accessibility in the design of websites.

\section{INSERT FIGURE 1 ABOUT HERE}

\subsection{Inclusion of the Blind Users}

Contrary to what appears to be prior student perceptions of accessibility, it is worth noting that in their final exams the students were usually the most excited by the work that they had done with the blind users. As such, it was not that they were prejudiced about the work, but rather they did not see the relevance of "accessibility" to their own careers. This finding suggests that there is still work to be done in making accessibility and Universal Access more mainstream concepts.

Whether the inclusion of a blind user in the user trials represents sufficient coverage of the issues around designing for Universal Access is a valid point for discussion. Some groups chose of their own volition to recruit additional users beyond the remit of a blind person. The most common solution was to include a 
grandparent to examine the effects of ageing on the use of their web sites. Such thinking was encouraged.

From a more prosaic standpoint, though, the choice to include a blind user in the final evaluation sessions meant that the delivery of the course had to focus slightly more on the methods of accessibility for supporting blind access to web sites. This choice was largely driven by the availability of automated testing tools and other assistive technologies that the students could access during the course. As such, it was a reflection on where the majority of research activity in terms of computer accessibility has been focused and also where the majority of legal actions have arisen. As a comparison, for example, there are no commonly accepted automated tools available for simulating cognitive impairment. Designing for such impairments is still typically focused around design best practice recommendations [e.g. Keates et al., 2007].

However, the material delivered during the lectures did focus on all aspects of Universal Access including the prevalence of different functional impairment types. The students' attention was explicitly drawn to the comparatively small number of potential blind users of web services and other products and how research in the area of Universal Access has been somewhat disproportionate in that regard.

\subsection{Experimental Design and Analysis Pre-course}

It became apparent during the first iteration of the "Usability with Project" course that the students from a non-scientific background were struggling with the quantitative analysis elements of the project. It was clear, for example, that many of them had never been introduced to fundamental concepts such as probabilities and could not make the connection between a probability of 0.5 being the same as a $50 \%$ chance. Usability and accessibility analyses depend upon quite sophisticated statistical and scientific methods, such as the ability to define clear research questions, to set hypotheses and to then determine whether the empirical data collected is statistically significantly different from the respective null hypotheses. As such, and given the very limited statistical knowledge possessed 
by the students, much of the first iteration of the course had to be given over to teaching the necessary scientific method and statistics.

To allow the course to focus more on the usability and accessibility theory and practice, a new pre-course was introduced - "Experimental Design and Analysis." This course ran in the second semester of the degree programme and taught basic statistics, assuming no previous knowledge. It covered from basic probabilities all the way up to multivariate analysis of variance.

Following the introduction of that course, the overall quality of reports submitted for the "Usability with Project" and "Usability and Accessibility" courses improved substantially, with the students being able to better understand the role of the statistical tests and spontaneously performing Kolmogorov-Smirnov or Q-Q plot analyses to ensure that the data was normally-distributed before applying a paired Student t-test or ANOVA. If the data was not distributed normally, they typically performed a Wilcoxon signed-rank test.

This was remarkable in students that often had no statistical training prior to the "Experimental Design and Analysis" course. Following the introduction of that course, no students lost marks because of incorrect statistical analyses in their projects and the overall quality of the usability and accessibility analyses, and the final reports, improved substantially.

\subsection{Prevalence of Similar Courses in Other Universities}

While there is a healthy and growing research community around Universal Access, it is worth exploring to what extent taught courses in universities reflect the need for designing for the widest possible user base. To explore this, 20 universities were selected using a random number generator from the 101 universities listed the Guardian Subject League Tables 2014 [Guardian, 2014] for Computer Sciences and IT courses.

A search was conducted on each of the 20 university web sites to find any undergraduate or postgraduate courses under the general headings of Computer Science, Computing and IT that offered modules that could be considered to be 
addressing user-centred design, in its broadest sense. Typical modules titles that may meet this criterion included words such as:

1. Human-Computer Interaction (or HCI)

2. User-centred design

3. Interaction

4. Human-Centric Computing

5. Human Factors

6. Usability

7. Accessibility

Table 4 shows the modules identified for undergraduate level courses and Table 5 shows the same for postgraduate level courses.

INSERT TABLE 4 ABOUT HERE

INSERT TABLE 5 ABOUT HERE

It can be seen that at the undergraduate level 6 universities offer no modules that meet the selection criteria. Of those universities that do so, 6 only offer the modules as options. Even of those that do offer core modules around user-centred design, HCI, and so on, those core modules are often only for some of the courses, such as those titles listed. There are often similar courses listed at the same institutions that do not require the same core modules. Consequently, it can be considered that undergraduate tuition of these topics is patchy, to say the least.

It is a very similar picture at the postgraduate level. Twelve universities offer no modules that meet the descriptors listed above. Of the 8 that do, 5 offer the modules as options and only 3 as core modules, only for the degree courses listed.

Of all the modules listed, the notions of "accessibility" or "Universal Access" are only mentioned explicitly in either the title or the online description of module content in one single module, "Designing Usable and Accessible Technologies" at Southampton, and even that module is an optional one. Matters do not improve 
much for the notion of "usability" either with only two modules referring to "usability" or "usable" in the title. Very few online module descriptors include either word as well, although it could be considered that the notion is implicit in titles such as "human-centric" and "human factors."

However, a more positive picture of how many students are being presented with the possibility of learning about Universal Access, usability and accessibility, can be drawn by adopting a different search heuristic. Table 6 shows a different set of university courses at universities that have strong track records in research in Universal Access.

\section{INSERT TABLE 6 ABOUT HERE}

On a quick inspection of Table 6, it can be seen that universities that have active research groups in this area appear to be more likely to offer taught modules covering these topics. The sample size is too small for meaningful statistical analysis, though is strongly suggestive that perhaps the most effective mechanism for increasing the availability of such modules to students is the presence of a Universal Access champion to push for their inclusion in the curricula.

\subsection{Further Course Developments}

The Usability and Accessibility course stopped being delivered in this format when the author moved to the UK. A new course with the same title, but different content, was developed to replace it. Interestingly, that course has now been retitled to "Usability and User Experience - Methods and Communication".

However, there are still lessons that can be learned over how the course could potentially be improved, especially in view of continuing research in this area. For example, the reason the course was discontinued in this format was because its delivery was dependent upon the skills of the author who has over 20 years of experience in designing for Universal Access. One obvious follow-on activity would thus be the development of a course that could be delivered by someone without such an extensive background in this area. An option for supporting this 
would be the development of a freely available on-line resource containing much of the core material required for this type of course.

Another limitation of this course structure was the requirement that students be competent in the development of web-shops. As such, the students needed quite advanced HTML and JavaScript-type skills. It would be useful if a more generic lecture course could be developed for more general purpose inclusive design skills for, say, product or engineering design students.

\section{Conclusions}

Overall, the "Usability and Accessibility" course, and its "Usability with Project" predecessor, provided a model for teaching both usability and accessibility theory and practice within the later stages of a Bachelor or in a Master's programme. It showed that students from a wide variety of backgrounds could respond positively to the challenges presented by the course. The student response to the course was very positive.

The students, in general, felt highly motivated at the end of the course. Many were especially inspired by the blind users they worked with at the end of the course. This interaction with users who would typically be outside of their prior experience gave them a way to personalise the need for universal access. The students were also able to note differences between the accessibility checker tool results and the user results. Some features that Cynthia Says and WAVE passed as satisfactory caused significant problems for some of the blind users. Such results served to reinforce the need for user involvement in accessibility and usability evaluations to the students.

It is worth noting that, based on LinkedIn profile data, approximately $75 \%$ of students who enrolled on either the "Usability with Project" or "Usability and Accessibility" courses have gone on to find usability jobs in industry or for government agencies.

It was also clear that the introduction of the Experimental Design and Analysis pre-course improved the quality of the student work substantially. The 
introduction of that pre-course was met with skepticism by some, who thought that students would be turned off by such an overtly mathematical topic.

However, on all iterations except one, the course was over-subscribed, with students from the Computer Games line in particular also seeking to enroll on it. That evidence suggests that students, especially more mature students, are aware of the importance of mathematics as a subject.

However, there was cause for concern over the tailing off of the number of students enrolling in the main course following the name change to "Usability and Accessibility" from "Usability with Project". This decline in numbers suggests that "accessibility," and by extension universal access, is still widely perceived as a niche interest rather than a mainstream activity within the student community, at least in Denmark. Since the students on the DDK course are mature students and have experience in industry before enrolling in the programme, this suggests that this attitude is also widespread in Danish industry. This is clearly a challenge that needs to be met.

In a wider context, it can be argued that for more students to be able to benefit from modules of this kind, Universal Access champions are needed at more universities to ensure their inclusion in more curricula. If not, it is very likely that Universal Access will remain a niche topic.

\section{References}

- ACM (2014) ACM Special Interest Group on Computer Human Interaction: SIGCHI Conference Publications Format. Available at: http://www.sigchi.org/publications/chipubform (accessed October 25, 2014)

- $\quad$ Adlin, T., Pruitt, J. (2010) The Essential Persona Lifecycle: Your Guide to Building and Using Personas. Morgan Kaufman, San Francisco

- Bigham, J.P., Prince, C.M. (2007) WebAnywhere: a screen reader on-the-go. In: Proceedings of the 9th International ACM SIGACCESS conference on Computers and accessibility. pp. 225-226

- Cambridge University Engineering Department (CUED) (2005) Inclusive design Exclusion calculator. Available at: http://www.eng.cam.ac.uk/inclusivedesign/index.php?section=data\&page=exclusion_calc (accessed October 25, 2014) 
- Cambridge University Engineering Department (CUED) (2013) Inclusive design toolkit Exclusion calculator. Available at:

http://www.inclusivedesigntoolkit.com/betterdesign2/exclusioncalc/exclusioncalc.html (accessed October 25, 2014)

- Clarkson, P.J., Coleman, R., Lebbon, C., Keates, S. (2003) Inclusive Design - Designing for the whole population. Springer, London

- Clarkson, P.J. and Keates, S. (2002) Quantifying design exclusion. In: Keates, S., Clarkson, P.J., Langdon, P.M., Robinson, P. (Eds.), Universal Access and Assistive Technology (pp. 23-32). Springer, London

- Cooper, A. (1999) The inmates are running the asylum. SAMS Publishing, Indianapolis

- Follette Story, M. (2001). The principles of universal design. In: Preiser, W., and Ostroff, E. (Eds.) Universal design handbook. McGraw-Hill, New York

- Freedom Scientific (2014) JAWS for Windows: Screen reading software. Available at: http://www.freedomscientific.com/Products/Blindness/JAWS (accessed October 25, 2014)

- Guardian (2014) University guide 2014: league table for computer sciences and IT. Available at: http://www.theguardian.com/education/table/2013/jun/04/university-guidecomputer-sciences-it (accessed October 25, 2014)

- Her Majesty’s Stationery Office (HMSO) (1995) UK Disability Discrimination Act 1995. Available at: http://www.legislation.gov.uk/ukpga/1995/50/contents (accessed October $25,2014)$

- HiSoftware (2013) HiSoftware ${ }^{\circledR}$ Cynthia Says ${ }^{\text {TM }}$ Portal. Available at: http://www.cynthiasays.com/ (October 25, 2014)

- Hudson, W. (2005) Playing your cards right: getting the most from card sorting for navigation design. Interactions. 12(5), pp. 56-58

- $\quad$ ISO (1998) ISO 9241-11:1998 Ergonomic requirements for office work with visual display terminals (VDTs) -- Part 11: Guidance on usability.

- $\quad$ Keates, S., Clarkson, P.J. (2003) Countering design exclusion - An introduction to inclusive design. Springer, Heidelberg

- Keates, S. (2007) Designing for accessibility: A business guide to countering design exclusion. Lawrence Erlbaum Associates, Mahwah, NJ

- $\quad$ Keates, S., Adams. R., Bodine, C., Czaja, S., Gordon, W., Gregor, P., Hacker, E., Hanson, V., Kemp, J., Laff, M., Lewis, C., Pieper, M., Richards, J., Rose, D., Savidis, A., Schultz, G., Snayd, P., Trewin, S., Varker, P. (2007) Cognitive and learning difficulties and how they affect access to IT systems. Int J on Universal Access in the Information Society, Springer, 5(4), 329-339

- Keates S, Lebbon C, Clarkson PJ (2000) Investigating industry attitudes to Universal Design. Proceedings of RESNA 2000 (Orlando, FL), RESNAPress, pp. 276-278

- Marcus, A. (2003) Universal, ubiquitous, user-interface design for the disabled and elderly. Interactions, 10(2), 23-27 
- Newell, A.F., Gregor, P. (2000) "User sensitive inclusive design"- in search of a new paradigm. In: Proceedings of the 2000 Conference on Universal Usability (CUU '00), pp. $39-44$

- Nielsen, J. (1993) Usability engineering. Morgan Kaufman, San Francisco

- Nielsen, J., Mack, R.L. (1994) Usability inspection methods. John Wiley and Sons, New York

- Stephanidis, C. (2009) The universal access handbook (1st ed.). CRC Press, Inc., Boca Raton

- $\quad$ Thatcher, J., Burks, M.R., Heilman, C., Henry, S.L., Kirkpatrick, A., Lauke, P.H., Lawson, B., Regan, B., Rutter, R., Urban, M., Waddell, C.D. (2006) Web accessibility: Web standards and regulatory compliance. Springer, New York

- US DoJ (1990) US Department of Justice: Americans with Disabilities Act of 1990. Available at: http://www.ada.gov/pubs/ada.htm (accessed October 25, 2014)

- Vanderheiden, G., and Tobias, J. (2000) Universal design of consumer products: Current industry practice and perceptions. In: Proceedings of the XIVth Triennial Congress of the International Ergonomics Association and 44th Annual Meeting of the Human Factors and Ergonomics Society, vol. 6, pp. 19-22

- Vischeck (2008) Vischeck. Available at: http://www.vischeck.com/ (accessed October $25,2014)$

- Vredenburg, K., Mao, J.-Y., Smith, P.W., Carey, T. (2002) A survey of user-centered design practice. In: Proceedings of the SIGCHI Conference on Human Factors in Computing Systems (CHI '02), pp. 471-478

- WebAIM (2014) WAVE - Web Accessibility Evaluation Tool. Available at: http://wave.webaim.org/ (accessed October 25, 2014) 


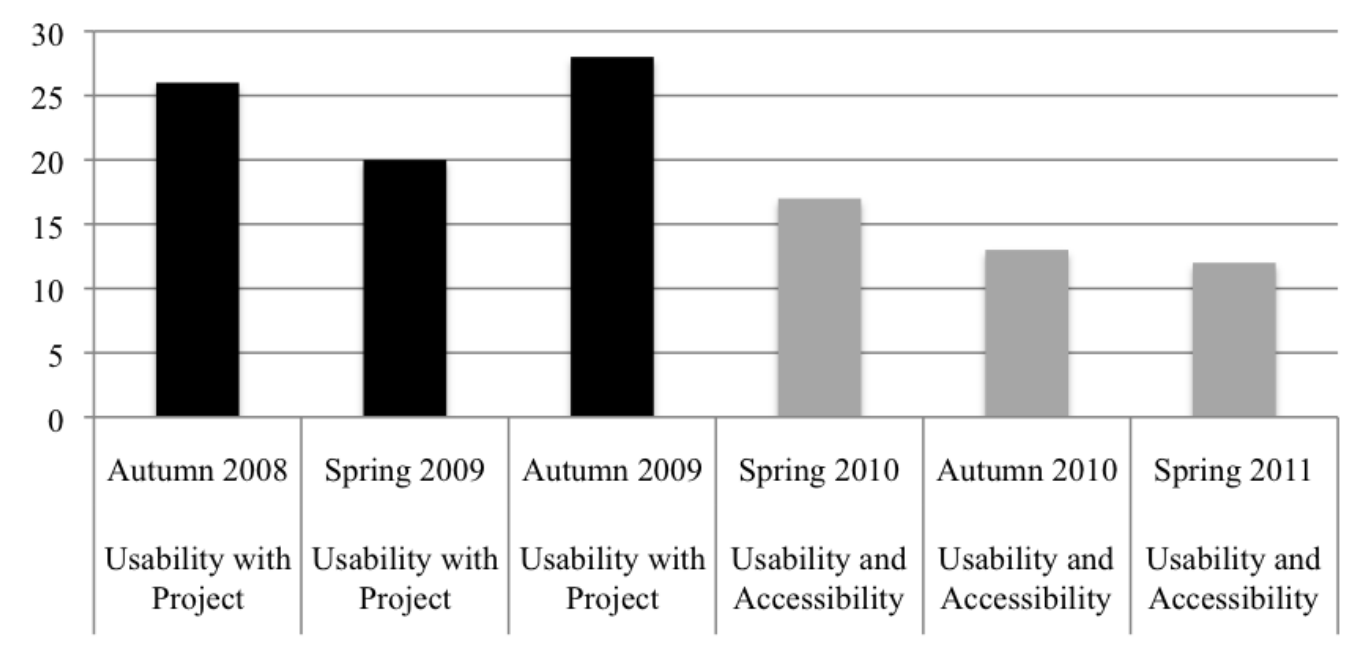

Fig. 1. Number of students enrolled for each semester of the "Usability with Project" and the "Usability and Accessibility" courses.

Table 1: The DDK study line for the M.Sc. degree at the IT University of Copenhagen

\begin{tabular}{|l|l|}
\hline Semester & Courses \\
\hline 1st Semester & "Interaction design" (15 ECTS) \\
\cline { 2 - 2 } & "Media and communication" (7.5 ECTS) \\
\cline { 2 - 2 } & "Web design and web communication" (7.5 ECTS) \\
& "Innovation and concept development" (7.5 ECTS) \\
\cline { 2 - 2 } & $\begin{array}{l}\text { "Introduction to coding, databases and system architecture" } \\
\text { (7.5. ECTS) }\end{array}$ \\
\cline { 2 - 2 } & Elective 1 (7.5 ECTS) \\
\cline { 2 - 2 } 3rd Semester & Elective 2 (7.5 ECTS) \\
\cline { 2 - 2 } & "Digital rhetoric" (7.5 ECTS) \\
\cline { 2 - 2 } & Elective 3 (7.5 ECTS) \\
\hline 4th Semester & Masters dissertation (30 ECTS) \\
\hline
\end{tabular}


Table 2: An example lecture and practical exercise plan for the "Usability with Project" /

"Usability and Accessibility” courses

\begin{tabular}{|c|c|c|}
\hline Week & Lecture topic & Practical exercises \\
\hline $1 / 2$ & Introduction to Project & $\begin{array}{l}\text { Design and develop a working web-shop } \\
\text { to the design specification }\end{array}$ \\
\hline 3 & Introduction to Usability & $\begin{array}{l}\text { (Theory) Card sorting exercise - } \\
\text { minimum number of button presses } \\
\text { (Project) Ensure that the products are in } \\
\text { the correct categories }\end{array}$ \\
\hline 4 & Discount Usability & $\begin{array}{l}\text { (Theory) Perform a heuristic usability } \\
\text { analysis of a car rental website } \\
\text { (Project) Perform a heuristic analysis of } \\
\text { own web-shop and one other group's } \\
\text { web-shop }\end{array}$ \\
\hline $5-7$ & Universal Access & $\begin{array}{l}\text { (Theory) Perform accessibility and } \\
\text { usability analyses of commercial web- } \\
\text { sites - is there a correlation between } \\
\text { accessibility and usability? } \\
\text { (Project) Perform accessibility analyses } \\
\text { of own web-shops }\end{array}$ \\
\hline $8-9$ & $\begin{array}{l}\text { Designing and } \\
\text { conducting user studies }\end{array}$ & $\begin{array}{l}\text { (Theory) Planning a comprehensive } \\
\text { usability evaluation of a product } \\
\text { (Project) Planning the user evaluation of } \\
\text { own web-shops }\end{array}$ \\
\hline 10 & Case studies & $\begin{array}{l}\text { (Theory) Performing a pilot user trial } \\
\text { (Project) Conduct a pilot user trial of own } \\
\text { web-shops }\end{array}$ \\
\hline 11 & Guest lectures & $\begin{array}{l}\text { (Project) Refine user evaluation } \\
\text { procedures for own web-shops }\end{array}$ \\
\hline 12 & Usability in businesses & (Project) Perform user evaluation trials \\
\hline $13-14$ & Complete Project work & and complete final reports \\
\hline 15 & End of semester & (Project) Hand in final reports \\
\hline
\end{tabular}


Table 3: A summary of the collected student views on each of the tools and methods used in the course.

\begin{tabular}{|c|c|c|}
\hline Tool / method & Sun & lary comments \\
\hline Card sorting & 1. & $\begin{array}{l}\text { Generally pretty useful, especially where } \\
\text { products were unknown }\end{array}$ \\
\hline Personas & $\begin{array}{l}2 . \\
3 .\end{array}$ & $\begin{array}{l}\text { Useful for encouraging students to think } \\
\text { about different user types and behaviours } \\
\text { Note: did not follow standard "persona" } \\
\text { practice }\end{array}$ \\
\hline $\begin{array}{l}\text { Discount usability methods } \\
\text { (heuristic analyses / } \\
\text { cognitive walkthroughs) }\end{array}$ & $\begin{array}{l}4 . \\
5 .\end{array}$ & $\begin{array}{l}\text { Good for identifying lots of problems } \\
\text { No real way of prioritising problems }\end{array}$ \\
\hline Pilot user study & $\begin{array}{l}6 . \\
7 . \\
8 .\end{array}$ & $\begin{array}{l}\text { Very effective for testing the final user } \\
\text { trial protocol, etc. } \\
\text { Generated some design feedback } \\
\text { Helped with debugging web-shops }\end{array}$ \\
\hline User trials & $\begin{array}{l}9 . \\
10 .\end{array}$ & $\begin{array}{l}\text { "Gold standard" for usability and } \\
\text { accessibility testing } \\
\text { A lot of effort to set up and conduct }\end{array}$ \\
\hline Cynthia Says & 11. & $\begin{array}{l}\text { Very detailed feedback - great for fixing } \\
\text { coding, though difficult to visualise }\end{array}$ \\
\hline WAVE & 12. & $\begin{array}{l}\text { Great summary feedback and very } \\
\text { visual, though more difficult to use for } \\
\text { coding }\end{array}$ \\
\hline Vischeck & $\begin{array}{l}13 . \\
14 . \\
15 .\end{array}$ & $\begin{array}{l}\text { Some functional limitations (i.e. did not } \\
\text { always work) } \\
\text { Helped identify potential colour issues } \\
\text { Could sometimes lead to unnecessary } \\
\text { aesthetic changes, not just functional } \\
\text { ones }\end{array}$ \\
\hline Screen readers & $\begin{array}{l}16 . \\
17 .\end{array}$ & $\begin{array}{l}\text { Webanywhere - great when it was } \\
\text { working (which was not always) } \\
\text { JAWS - very useful, though expensive } \\
\text { to purchase }\end{array}$ \\
\hline
\end{tabular}


Table 4: A summary of the modules identified in undergraduate degree courses for 20 randomly selected UK universities.

\begin{tabular}{|c|c|c|c|c|}
\hline University & $\begin{array}{l}\text { Example degree } \\
\text { title }\end{array}$ & Year & Module & Status \\
\hline \multirow[t]{2}{*}{ Cambridge } & \multirow[t]{2}{*}{$\begin{array}{l}\text { BSc Computer } \\
\text { Science }\end{array}$} & 1 & $\begin{array}{l}\text { Software and Interface } \\
\text { Design }\end{array}$ & Core \\
\hline & & 3 & $\mathrm{HCI}$ & Core \\
\hline \multirow[t]{2}{*}{ Southampton } & \multirow{2}{*}{$\begin{array}{l}\text { MEng Computer } \\
\text { Science }\end{array}$} & 2 & Interaction Design & Core \\
\hline & & 4 & $\begin{array}{l}\text { Designing Usable and } \\
\text { Accessible Technologies }\end{array}$ & Option \\
\hline Liverpool & $\begin{array}{l}\text { MEng Computer } \\
\text { Science }\end{array}$ & 1 & $\begin{array}{l}\text { Human-Centric } \\
\text { Computing }\end{array}$ & Core \\
\hline Loughborough & $\begin{array}{l}\text { BSc Computer } \\
\text { Science }\end{array}$ & 3 & Advanced HCI & Option \\
\hline Heriot Watt & $\begin{array}{l}\text { BSc Computer } \\
\text { Science }\end{array}$ & $\mathrm{n} / \mathrm{a}$ & $\mathrm{n} / \mathrm{a}$ & $\mathrm{n} / \mathrm{a}$ \\
\hline Warwick & $\begin{array}{l}\text { MEng Computer } \\
\text { Science }\end{array}$ & 1 & $\begin{array}{l}\text { Web Development } \\
\text { Technology }\end{array}$ & Option \\
\hline \multirow[t]{2}{*}{ Kent } & \multirow{2}{*}{$\begin{array}{l}\text { BSc Computer } \\
\text { Science }\end{array}$} & 1 & $\mathrm{HCI}$ & Core \\
\hline & & 1 & People and Computing & Core \\
\hline Cardiff & $\begin{array}{l}\text { BSc Computer } \\
\text { Science }\end{array}$ & 2 & $\mathrm{HCI}$ & Core \\
\hline Lincoln & $\begin{array}{l}\text { MComp } \\
\text { Computer } \\
\text { Science }\end{array}$ & $\mathrm{n} / \mathrm{a}$ & $\mathrm{n} / \mathrm{a}$ & $\mathrm{n} / \mathrm{a}$ \\
\hline De Montfort & BSc Computing & 2 & $\begin{array}{l}\text { Interactive Systems } \\
\text { Design and Evaluation }\end{array}$ & Core \\
\hline East Anglia & $\begin{array}{l}\text { MComp } \\
\text { Computer } \\
\text { Science }\end{array}$ & 4 & $\mathrm{HCI}$ & Option \\
\hline $\begin{array}{l}\text { Sheffield } \\
\text { Hallam }\end{array}$ & BSc Computing & 2 & $\mathrm{HCI}$ & Option \\
\hline
\end{tabular}




\begin{tabular}{|l|l|l|l|l|}
\hline Anglia Ruskin & $\begin{array}{l}\text { BSc Computer } \\
\text { Science }\end{array}$ & 2 & Interaction and Usability & Core \\
\hline Plymouth & $\begin{array}{l}\text { BSc Computer } \\
\text { Science }\end{array}$ & 2 & HCI & Core \\
\hline Leeds Beckett & BSc Computing & 3 & HCI & Option \\
\hline Cardiff Met & BSc Computing & $\mathrm{n} / \mathrm{a}$ & $\mathrm{n} / \mathrm{a}$ & $\mathrm{n} / \mathrm{a}$ \\
\hline $\begin{array}{l}\text { West of } \\
\text { Scotland }\end{array}$ & BSc Computing & $\mathrm{n} / \mathrm{a}$ & $\mathrm{n} / \mathrm{a}$ & $\mathrm{n} / \mathrm{a}$ \\
\hline London Met & $\begin{array}{l}\text { BSc Computer } \\
\text { Science }\end{array}$ & $\mathrm{n} / \mathrm{a}$ & $\mathrm{n} / \mathrm{a}$ & $\mathrm{n} / \mathrm{a}$ \\
\hline Westminster & $\begin{array}{l}\text { MEng Software } \\
\text { Engineering }\end{array}$ & 2 & $\begin{array}{l}\text { Human Computer } \\
\text { Interface Design }\end{array}$ & Core \\
\hline Bolton & BSc Computing & $\mathrm{n} / \mathrm{a}$ & n/a & n/a \\
\hline
\end{tabular}

Table 5: A summary of the modules identified in postgraduate degree courses for 20 randomly selected UK universities.

\begin{tabular}{|c|c|c|c|}
\hline University & $\begin{array}{l}\text { Example degree } \\
\text { title }\end{array}$ & Module & Status \\
\hline Cambridge & $\begin{array}{l}\text { MPhil Advanced } \\
\text { Computer Science }\end{array}$ & $\mathrm{n} / \mathrm{a}$ & $\mathrm{n} / \mathrm{a}$ \\
\hline Southampton & $\begin{array}{l}\text { MEng Computer } \\
\text { Science }\end{array}$ & $\begin{array}{l}\text { Designing Usable and } \\
\text { Accessible Technologies }\end{array}$ & Option \\
\hline Liverpool & $\begin{array}{l}\text { MSc Advanced } \\
\text { Computer Science }\end{array}$ & $\mathrm{n} / \mathrm{a}$ & $\mathrm{n} / \mathrm{a}$ \\
\hline Loughborough & $\begin{array}{l}\text { MSc Advanced } \\
\text { Computer Science }\end{array}$ & $\mathrm{n} / \mathrm{a}$ & $\mathrm{n} / \mathrm{a}$ \\
\hline Heriot Watt & MSc IT & $\mathrm{n} / \mathrm{a}$ & $\mathrm{n} / \mathrm{a}$ \\
\hline Warwick & $\begin{array}{l}\text { MEng Computer } \\
\text { Science and } \\
\text { Applications }\end{array}$ & $\mathrm{n} / \mathrm{a}$ & $\mathrm{n} / \mathrm{a}$ \\
\hline Kent & $\begin{array}{l}\text { MSc Computer } \\
\text { Science Conversion }\end{array}$ & $\mathrm{n} / \mathrm{a}$ & $\mathrm{n} / \mathrm{a}$ \\
\hline Cardiff & $\begin{array}{l}\text { MSc Advanced } \\
\text { Computer Science }\end{array}$ & Human-Centric Computing & Option \\
\hline
\end{tabular}




\begin{tabular}{|c|c|c|c|}
\hline Lincoln & $\begin{array}{l}\text { MSc Computer } \\
\text { Science }\end{array}$ & Interaction Design & Core \\
\hline De Montfort & $\begin{array}{l}\text { MSc Computer } \\
\text { Science }\end{array}$ & $\begin{array}{l}\text { Human Factors in Systems } \\
\text { Design }\end{array}$ & Core \\
\hline East Anglia & $\begin{array}{l}\text { MComp Computer } \\
\text { Science }\end{array}$ & $\mathrm{HCI}$ & Option \\
\hline $\begin{array}{l}\text { Sheffield } \\
\text { Hallam }\end{array}$ & $\begin{array}{l}\text { MSc Computer } \\
\text { Science }\end{array}$ & $\mathrm{n} / \mathrm{a}$ & $\mathrm{n} / \mathrm{a}$ \\
\hline Anglia Ruskin & $\begin{array}{l}\text { MSc Computer } \\
\text { Science }\end{array}$ & $\mathrm{n} / \mathrm{a}$ & $\mathrm{n} / \mathrm{a}$ \\
\hline Plymouth & $\begin{array}{l}\text { MSc Computer } \\
\text { Science }\end{array}$ & $\mathrm{n} / \mathrm{a}$ & $\mathrm{n} / \mathrm{a}$ \\
\hline Leeds Beckett & $\begin{array}{l}\text { MSc Information } \\
\text { and Technology }\end{array}$ & User Experience Design & Option \\
\hline Cardiff Met & MSc Computing & $\mathrm{n} / \mathrm{a}$ & $\mathrm{n} / \mathrm{a}$ \\
\hline $\begin{array}{l}\text { West of } \\
\text { Scotland }\end{array}$ & $\begin{array}{l}\text { MSc Advanced } \\
\text { Computer Systems } \\
\text { Development }\end{array}$ & $\begin{array}{l}\text { Interactive Design for Smart } \\
\text { Devices }\end{array}$ & Option \\
\hline London Met & $\begin{array}{l}\text { MSc Computer } \\
\text { Science }\end{array}$ & $\mathrm{n} / \mathrm{a}$ & $\mathrm{n} / \mathrm{a}$ \\
\hline Westminster & MSc Multimedia & User-Centred Interface Design & Core \\
\hline Bolton & $\begin{array}{l}\text { MA Games } \\
\text { Development }\end{array}$ & $\mathrm{n} / \mathrm{a}$ & $\mathrm{n} / \mathrm{a}$ \\
\hline
\end{tabular}

Table 6: A summary of the modules identified in undergraduate and postgraduate degree courses for universities with active research in Universal Access.

\begin{tabular}{|l|l|l|l|}
\hline University & $\begin{array}{l}\text { Example degree } \\
\text { title }\end{array}$ & Module & Status \\
\hline York & $\begin{array}{l}\text { MEng Computer } \\
\text { Science }\end{array}$ & $\begin{array}{l}\text { Human Aspects of Computer } \\
\text { Science }\end{array}$ & Core \\
\hline & MSc Computing & User Centred Design & Core \\
\hline & $\begin{array}{l}\text { MSc Human- } \\
\text { Centred Interactive } \\
\text { Technologies }\end{array}$ & User Centred Design & Core \\
\hline
\end{tabular}




\begin{tabular}{|l|l|l|l|}
\hline Dundee & $\begin{array}{l}\text { BSc Applied } \\
\text { Computing }\end{array}$ & People-Centred Computing & Core \\
\hline & $\begin{array}{l}\text { MSc Augmentative } \\
\text { and Alternative } \\
\text { Communication }\end{array}$ & Accessibility and Computing & Option \\
\hline [Multiple modules] & Core \\
\hline Southampton & $\begin{array}{l}\text { MEng Computer } \\
\text { Science }\end{array}$ & $\begin{array}{l}\text { Designing Usable and } \\
\text { Accessible Technologies }\end{array}$ & Option \\
\hline Abertay & $\begin{array}{l}\text { BSc Web, Design } \\
\text { and } \\
\text { Communication }\end{array}$ & HCI - User Centred Design & Option \\
\hline Greenwich & $\begin{array}{l}\text { MEng Engineering } \\
\text { for Intelligent } \\
\text { Systems }\end{array}$ & User-Centred Design & Core \\
\hline
\end{tabular}

